\title{
Peran prostaglandin pada pergerakan gigi ortodontik
}

\author{
*Patricia Iskandar, **Nia Ayu Ismaniati \\ *Peserta Program Pendidikan Dokter Gigi Spesialis Ortodonti \\ ***Departemen Ortodonti
}

Fakultas Kedokteran Gigi, Universitas Indonesia

Jakarta Pusat, Indonesia

\begin{abstract}
Orthodontic tooth movement is a complex process, in which cellular and chemical changes occur. When a force is applied onto a tooth, it causes tissue injury, compression of periodontal ligament and bone deformation. These procedures lead to followed by certain biochemical reactions at cellular level which results in bone remodeling. Thus a process of signal transduction occurs. In this process, some messengers are released, including prostaglandin. Prostaglandin is an arachidonic acid metabolite, released when cell membrane is deformed. Prostaglandin, particularly $P G E_{2}$, play a role in bone metabolism and orthodontic tooth movement. Prostaglandin will stimulate the release of second messengers, i.e. cAMP and calcium intracellular. These second messengers will activate osteoclasts. Prostaglandin will also induce RANKL (receptor activator of nuclear factor $\kappa \beta$ ligand) to initiate osteoclasts differentiation. Some researchers proved that application of prostaglandin in orthodontic treatment can accelerate tooth movement.
\end{abstract}

Key words: prostaglandin, orthodontic tooth movement, bone remodeling

\begin{abstract}
ABSTRAK
Pergerakan gigi ortodontik merupakan suatu proses yang kompleks, terjadi perubahan selular dan kimiawi. Gaya ortodontik akan menyebabkan trauma jaringan, kompresi ligamen periodontal, dan deformasi tulang. Kejadian ini diikuti dengan reaksi biokimia pada tingkat sel, yang menghasilkan remodeling tulang. Dengan demikian terjadi transduksi sinyal, yaitu beberapa molekul messenger, termasuk prostaglandin, dilepaskan. Prostaglandin adalah hasil metabolisme asam arakidonat yang dilepaskan ketika membran sel mengalami deformasi. Prostaglandin, terutama $\mathrm{PGE}_{2}$, berperan dalam metabolisme tulang, dan juga terlibat dalam proses pergerakan gigi. Prostaglandin yang dilepaskan akan menstimulasi pelepasan messenger kedua, yaitu cAMP dan kalsium intraselular, yang kemudian akan mengaktifkan osteoklas. Selain itu, prostaglandin akan memicu receptor activator of nuclear factor $\kappa \beta$ ligand (RANKL) untuk menginisiasi diferensiasi osteoklas. Diketahui bahwa pemberian prostaglandin pada perawatan ortodontik dapat mempercepat pergerakan gigi.

Kata kunci: prostaglandin, pergerakan gigi ortodontik, remodeling tulang

Korespondensi: Patricia Iskandar, peserta Program Pendidikan Dokter Gigi Spesialis Ortodonti, Fakultas Kedokteran Gigi Universitas Indonesia. Jl. Salemba Raya No. 4, Jakarta Pusat, Indonesia. E-mail: p4t05@yahoo.com.
\end{abstract}

\section{PENDAHULUAN}

Perawatan ortodontik dilakukan berdasarkan prinsip bahwa bila suatu tekanan diberikan pada gigi dengan jangka waktu tertentu, akan terjadi pergerakan gigi karena ligamen periodontal dan tulang di sekeliling gigi mengalami perubahan (remodeling). Ketika tekanan diaplikasikan pada mahkota gigi, maka tekanan tersebut akan 
diteruskan melalui akar gigi ke ligamen periodontal dan tulang alveolar, dan akan menimbulkan daerah tekanan dan daerah regangan. Pada daerah tekanan akan terjadi resorpsi tulang sebagai respons terhadap tekanan tersebut, sedangkan pada daerah regangan akan terjadi aposisi tulang untuk mempertahankan keutuhan dan mekanisme perlekatan gigi ke tulang. Akibatnya, soket dari gigi akan bergerak, sejalan dengan pergerakan dari gigi melalui tulang alveolar. Walaupun proses ini rumit dan belum dapat dimengerti sepenuhnya, tuntutan profesionalisme mengharuskan ortodontis untuk memiliki pengetahuan mengenai prinsip biologis yang mendasari perawatan ortodontik. ${ }^{1-7}$

Deformasi mekanis yang disebabkan oleh gaya ortodontik akan menyebabkan perubahan pada sel-sel ligamen periodontal dan tulang, yaitu terjadi pelepasan berbagai molekul messenger secara kimiawi, diantaranya prostaglandin, yang kemudian akan mempengaruhi sel-sel yang bertanggung jawab dalam remodeling tulang. ${ }^{3}$

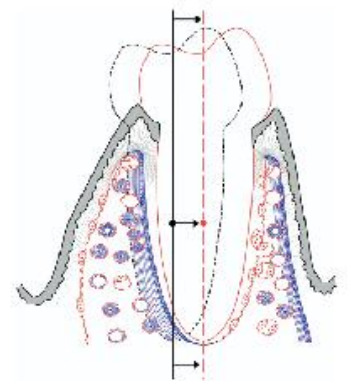

Gambar 1. Gambar skematik yang menunjukkan fisiologi tulang yang dihubungkan dengan pergerakan translasi gigi. Aktivitas osteoklast ditunjukkan dengan warna merah, sedangkan aktivitas osteoblast ditunjukkan dengan warna biru. (Sumber: Roberts WE, Roberts JA, Epker BN, Burr DB, Hartsfield JK. Remodeling of mineralized tissues, part I: The forst legacy. Semin Orthod 2006; 12: 216-37). ${ }^{11}$

Berbagai penelitian dilakukan untuk mempelajari peran prostaglandin sebagai perantara pergerakan gigi. Prostaglandin dianggap sebagai modulator dari resorpsi dan pembentukan tulang, yang terbentuk secara lokal sebagai akibat stres fisik. Aplikasi gaya ortodonti menyebabkan peningkatan sintesis prostaglandin, yang kemudian akan menstimulasi terjadinya resoprsi tulang oleh osteoklas. Pemberian prostaglandin secara lokal pada daerah gingiva dekat gigi yang akan digerakkan, akan menyebabkan kecepatan pergerakan gigi meningkat hampir dua kali lipat. $^{4,8,9}$

Berdasarkan latar belakang tersebut, telaah pustaka ini dibuat untuk menggali lebih dalam lagi mengenai aspek biologis, khususnya peran prostaglandin pada pergerakan gigi ortodontik. Dengan demikian, diharapkan akan menambah pengetahuan dan pemahaman mengenai prinsip biologis yang mendasari perawatan ortodontik serta perkembangannya.

\section{TINJAUAN PUSTAKA}

\section{Pergerakan gigi ortodontik}

Pergerakan gigi terjadi sebagai akibat langsung dari remodeling jaringan di sekitar akar gigi oleh karena adanya gaya yang diberikan. Remodeling memerlukan adanya sel-sel yang dapat meresorpsi dan membentuk matriks ekstraseluler dari ligamen periodontal dan tulang alveolar. Ketika gaya ortodontik diaplikasikan, ligamen periodontal akan menyempit pada sisi yang mengalami tekanan, diikuti dengan resorpsi tulang alveolar akibat aktivitas osteoklas. Sebaliknya, pada sisi regangan terjadi aposisi tulang oleh osteoblas (Gambar 1). ${ }^{10}$ Hal ini juga dibuktikan secara histologis oleh Standstedt, dikutip oleh Robert dkk., ${ }^{11}$ yang menemukan adanya sel-sel osteoklas multinuklear dalam lakuna Howship pada sisi tekanan dan terbentuknya tulang baru pada dinding alveolar pada sisi regangan. 
Gaya ortodontik yang diaplikasikan pada gigi akan menyebabkan terjadinya serangkaian kejadian yang diinisiasi oleh deformasi mekanis

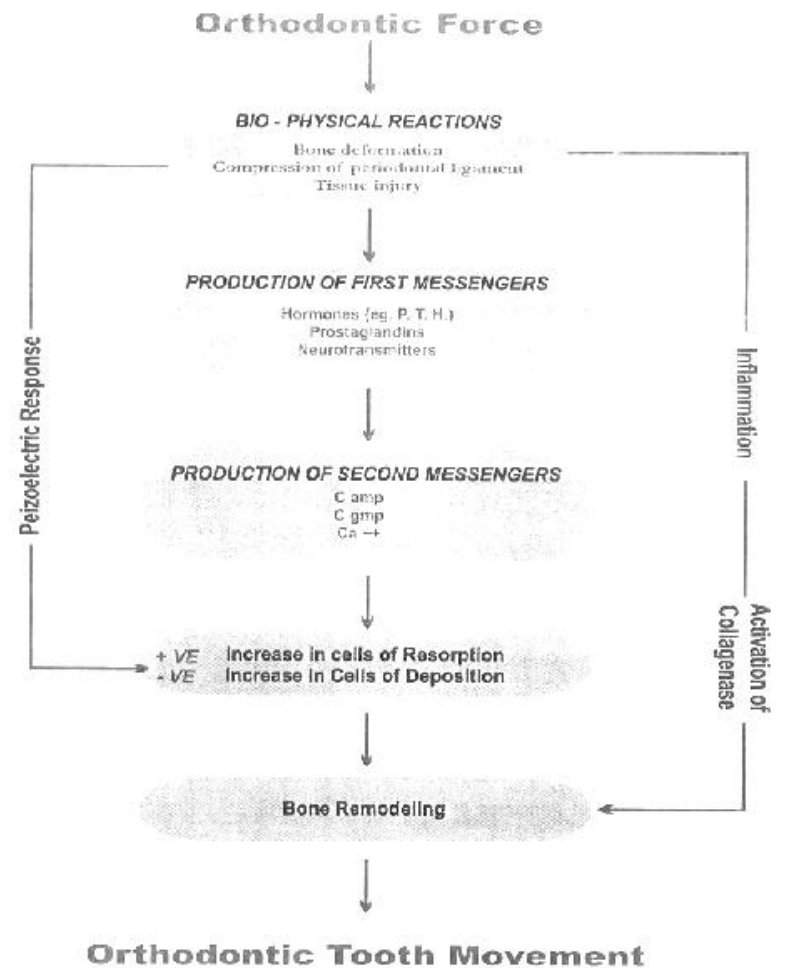

Gambar 2. Reaksi biokimia terhadap gaya ortodontik (Sumber: Cardaropoli D, Gaveglio L. The influence of orthodontic movement on periodontal tissues level. Semin Orthod 2007; 13: 234-45). ${ }^{10}$

dari sel-sel dan matriks ekstraseluler. Deformasi tulang, kompresi ligamen periodontal, dan trauma jaringan menyebabkan pelepasan beberapa molekul ekstraseluler yang membawa sinyal, disebut messenger pertama, termasuk di dalamnya hormon paratiroid, neurotransmiter dan prostaglandin. Perubahan bentuk sel akan menyebabkan pelepasan asam arakidonat dari permukaan sel yang menuntun pada pelepasan prostaglandin dan leukotrin melalui jalur siklooksigenase maupun jalur lipo-oksigenase. Messenger pertama akan berikatan dengan reseptor yang ada di permukaan sel target dan menginisiasi proses sinyal intraseluler. Hal ini menstimulasi pelepasan messenger kedua, termasuk cAMP, cGMP, dan kalsium intraseluler.
Pembentukan messenger kedua di dalam sel diyakini menginisiasi pembentukan sel tulang (Gambar 2). Selain melalui pembentukan messenger pertama dan kedua, terdapat jalur biologis alternatif untuk pergerakan gigi ortodontik. Gaya ortodontik juga menyebabkan trauma jaringan dalam jumlah tertentu. Setelah itu, enzim hidrolitik akan dilepaskan yang kemudian akan mengaktifkan enzim kolagenase yang menyebabkan resorpsi tulang., ${ }^{3,10}$

Pergerakan gigi yang terjadi akibat aplikasi gaya ortodontik menyebabkan terjadinya proses inflamasi. Hal ini dibuktikan oleh Yamasaki dkk, yang dalam penelitiannya menemukan bahwa aplikasi gaya ortodontik segera akan menyebabkan penurunan jumlah sel mast yang dapat diwarnai dengan toluidin biru, yang menandakan terjadinya inflamasi. Penurunan jumlah sel mast ini terjadi lebih banyak pada sisi tekanan dari pada sisi regangan dari ligamen periodontal gigi yang mendapat gaya ortodontik, walaupun perbedaannya tidak signifikan. Proses inflamasi yang terjadi terdiri dari degranulasi granula intraselular, peningkatan permeabilitas vaskular, perubahan degeneratif dan reformatif pada ligamen periodontal, sintesis dan sekresi prostaglandin, yang kemudian diikuti dengan remodeling tulang. ${ }^{12}$

Pergerakan gigi ortodontik melibatkan proses remodeling tulang yang dipengaruhi oleh sel osteoblas yang selain membentuk tulang, juga bertanggung jawab atas pengaktifan dan perekrutan prekursor osteoklas. Terdapat hubungan antara osteoblas dan osteoklas, diidentifikasi adanya suatu faktor perantara pada permukaan osteoblas yang bertanggung jawab terhadap terjadinya osteoklastogenesis. Faktor tersebut adalah receptor activator of nuclear factor $\kappa \beta$ ligand (RANKL). RANKL akan berikatan pada reseptornya, yaitu receptor 
activator of nuclear factor $\kappa \beta$ (RANK) yang terdapat pada permukaan sel progenitor osteoklas, ikatan ini akan merangsang osteoklastogenesis dan mengaktifkan osteoklas, yang akhirnya menyebabkan peningkatan resorpsi tulang (Gambar 3). ${ }^{7,13}$

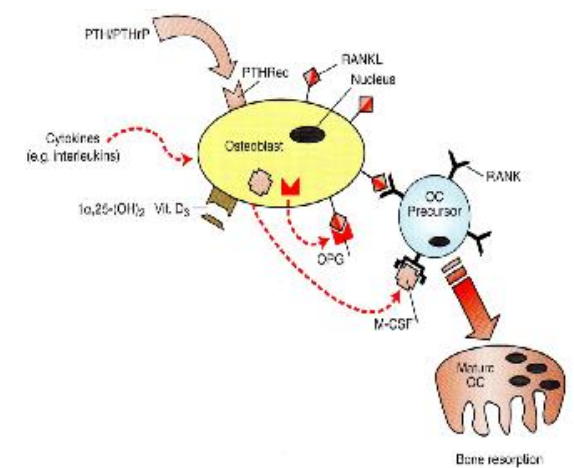

Gambar 3. Pengaturan osteoklastogenesis oleh osteoblas (Sumber: Smith JB. Prostaglandin and related eicosanoids. In: DiPalma JR, DiGregorio GJ (Ed). Basic pharmacology in medicine. $3^{\text {rd }}$ ed. New York: McGraw-Hill Publishing Company; 1990. p.181-7). ${ }^{13}$

Selain itu, remodeling tulang juga dipengaruhi oleh mekanisme lokal yang melibatkan sitokin yang timbul dalam keadaan inflamasi, serta mekanisme sistemik yang melibatkan hormon paratiroid, vitamin $\mathrm{D}_{3}$, dan hormon seksual. Prostaglandin $\mathrm{E}_{2}$ akan berikatan dengan reseptor EP4 pada permukaan sel osteoblas, yang kemudian akan memicu RANKL untuk menginisiasi diferensiasi osteoklas. ${ }^{13}$

\section{Prostaglandin}

Prostaglandin merupakan messenger kimiawi yang dianggap sebagai kelompok hormon lokal yang disebut eikosanoid. Eikosanoid merupakan hormon parakrin, yaitu hormon yang bekerja hanya pada sel-sel yang berada dekat dengan tempat hormon tersebut disintesis. Eikosanoid terlibat dalam berbagai proses fisiologis dan patologis. Ada tiga kelas utama dari eikosanoid, yaitu tromboksan, leukotrin, dan prostaglandin. Tromboksan berperan dalam pembentukan bekuan darah (agregasi platelet) dan menyebabkan terjadinya vasokonstriksi. Leukotrin terlibat dalam inflamasi dan alergi, jika produksinya berlebihan dapat menyebabkan serangan asma. Prostaglandin bekerja pada banyak jaringan dengan cara mengatur sintesis cyclic AMP (cAMP). Oleh karena cAMP merupakan mediator dari kerja berbagai enzim, maka prostaglandin mempengaruhi fungsi sel dan jaringan secara luas. $^{8,14-17}$

Prostaglandin terdiri dari berbagai jenis (A, B, C, D, E, F, G, H, dan I) dan berbagai seri (seri 1, 2, dan 3) tergantung pada strukturnya.

Asam arakidonat terikat pada fosfolipid pada lapisan lipid ganda dari membran plasam sel. Oleh karena asam arakidonat tidak dapat disintesis di dalam tubuh, maka harus diperoleh dari makanan. Makanan utama yang merupakan prekursor untuk sintesis asam arakidonat adalah asam lemak esensial linoleat ( $\omega-6)$, yang terdapat dalam minyak nabati. Jika terjadi deformasi pada membran sel, atau adanya stimulus seperti histamin dan sitokin, maka asam arakidonat akan dilepaskan dari lapisan lipid ganda oleh enzim fosfolipase A atau C. ${ }^{5,17-19}$

Setelah asam arakidonat dilepaskan ke dalam sitosol, akan diubah menjadi eikosanoid oleh berbagai enzim yang kerjanya bervariasi. Asam arakidonat secara enzimatik dimetabolisme melalui tiga jalur utama, berturut-turut, siklooksigenase yang menghasilkan prostaglandin dan tromboksan, lipoksigenase menghasilkan leukotrin, HETEs (hydroxyeicosatetraenoic acids) dan lipoksin, dan dikatalisis oleh sistem sitokrom P450, yang bertanggung jawab untuk sintesis epoksid, HETEs dan diHETEs. ${ }^{14,17-19}$

Proses konversi asam arakidonat menjadi prostaglandin memerlukan suatu enzim 
siklooksigenase. Pada tahun 1990-an, ditemukan bahwa enzim siklooksigenase (COX) terdapat dalam 2 isoform yang berbeda, yaitu COX-1 dan COX-2. COX-1 dianggap sebagai bentuk dasar dari enzim ini, terdapat pada hampir semua jaringan. COX-1 memiliki fungsi housekeeping, seperti mempertahankan aliran darah ginjal, sitoproteksi lambung, dan homeostasis. Kadar COX-2 rendah bila berada pada jaringan sehat, tetapi tinggi pada jaringan yang terinflamasi. COX-2 merupakan enzim yang kadarnya akan dipicu terutama oleh mediator pro-inflamasi dan menuntun pada pembentukan prostaglandin yang terlibat dalam proses patofisiologis, seperti terjadinya edema, hiperalgesia, dan demam. ${ }^{16,18-23}$

Prostaglandin terdapat dalam jumlah yang sangat banyak pada jaringan tulang dan diproduksi oleh osteoblas dan sel-sel hematopoietik di sekitarnya. Prostaglandin, terutama $\mathrm{PGE}_{2}$, berperan sebagai inhibitor maupun stimulator dalam metabolisme tulang, bergantung pada kondisi fisiologis atau patologis. Efek anabolik terjadi terutama sebagai respons tulang terhadap pemberian beban mekanik dan pada penyembuhan fraktur tulang, sedangkan resorpsi tulang yang diperantarai oleh $\mathrm{PGE}_{2}$ secara signifikan akan memperbesar terjadinya kehilangan tulang pada penyakit inflamasi dan sebagai respons terhadap immobilisasi yang berkepanjangan. ${ }^{19,22-23} \quad \mathrm{PGE}_{2}$ adalah stimulator resorpsi tulang yang kuat dengan cara meningkatkan replikasi dan diferensiasi prekursor osteoklas. ${ }^{24}$

Prostaglandin memiliki efek stimulasi dan inhibisi terhadap sintesis kolagen tulang mungkin disebabkan karena perbedaan pada reseptor dan jalur transduksi sinyal pada sel-sel osteoblastik. Pada sel osteoblas, terdapat berbagai reseptor, termasuk suatu reseptor selektif untuk prostaglandin jenis E (reseptor EP). Reseptor EP memiliki sejumlah subjenis dan hal ini dapat menyebabkan respons seluler menjadi sangat kompleks dan heterogen. Peranan prostaglandin dalam proses anabolik tulang diperantarai oleh reseptor EP4..$^{20,25}$

\section{Prostaglandin dan pergerakan gigi ortodontik}

Sejumlah penelitian membuktikan bahwa prostaglandin dapat mempercepat pergerakan gigi dalam perawatan ortodontik, sehingga akan mempersingkat periode pergerakan gigi. Yamasaki dkk melakukan serangkaian penelitian untuk menguji peran prostaglandin sebagai mediator resorpsi tulang yang diinduksi oleh pergerakan gigi. Pada tahun 1980, penelitian yang dilakukan pada tikus menunjukkan bahwa semakin tinggi dosis prostaglandin yang diinjeksikan pada daerah submukosa gigi, semakin banyak osteoklas. Sebaliknya, pada pemberian indometasin, suatu inhibitor prostaglandin akan menurunkan jumlah osteoklas. ${ }^{26}$

Pada tahun 1982, Yamasaki dkk melakukan penelitian pada dua ekor monyet (Macaca fuscata). Prostaglandin $\mathrm{E}_{2}-\alpha$ cyclodextrin clathrate ( $\mathrm{PGE}_{2} . \mathrm{CD}$, Ono Company, Osaka, Japan) dilarutkan dalam larutan saline dengan konsentrasi $160 \mathrm{~g} / \mathrm{ml} . \quad 0,25 \quad \mathrm{ml} \quad \mathrm{PGE}_{2} . \mathrm{CD} \quad(40 \quad \mathrm{~g})$ diinjeksikan secara lokal pada daerah submukosa dari sisi distal gigi kaninus yang akan ditarik ke distal. ${ }^{9}$ Selanjutnya pada tahun 1984 , Yamasaki melakukan penelitian ini secara klinis pada manusia. Dalam penelitian ini, digunakan $\mathrm{PGE}_{1}-\alpha$ cyclodextrin clathrate $\left(\mathrm{PGE}_{1} . \mathrm{CD}, \quad \mathrm{Ono}\right.$ Pharmaceutical Company, Osaka, Japan) dilarutkan dalam larutan lidokain $2 \%$ yang mengandung $1,25 \times 10^{-3} \%$ epinefrin, dengan konsentrasi $\mathrm{PGE}_{1} 50 \mathrm{~g} / \mathrm{ml}$ untuk injeksi lokal. Injeksi dilakukan dengan syringe $1 \mathrm{ml}$ dan jarum 26 gauge, $1 / 2$ inci, pada daerah submukosa dekat gigi yang akan digerakkan (Gambar 6). ${ }^{24}$ Hasil dari kedua penelitian ini menunjukkan bahwa 
pergerakan gigi pada sisi yang menerima injeksi PGE hampir dua kali lebih cepat dibandingkan sisi kontrol. Tidak terdapat efek samping secara makroskopis pada gingiva, begitu juga pada pemeriksaan radiografi tulang alveolar. Beberapa pasien mengeluhkan rasa sakit ringan setelah efek anestesi menghilang, tetapi rasa sakit ini akan berkurang ke tingkat yang sama dengan pergerakan gigi ortodontik dalam dua jam. ${ }^{9,24}$

Beberapa peneliti lainnya juga melakukan eksperimen untuk melihat keterlibatan prostaglandin dalam pergerakan gigi ortodontik, antara lain Niaki dkk, ${ }^{27}$ serta Chumbley dan Tuncay. ${ }^{28}$ Mereka menemukan bahwa prostaglandin berperan signifikan dalam proses resorpsi tulang dan mempengaruhi kecepatan pergerakan gigi. Sedangkan pemberian indometasin, suatu obet seperti aspirin, akan menghambat pergerakan gigi. ${ }^{27-28}$

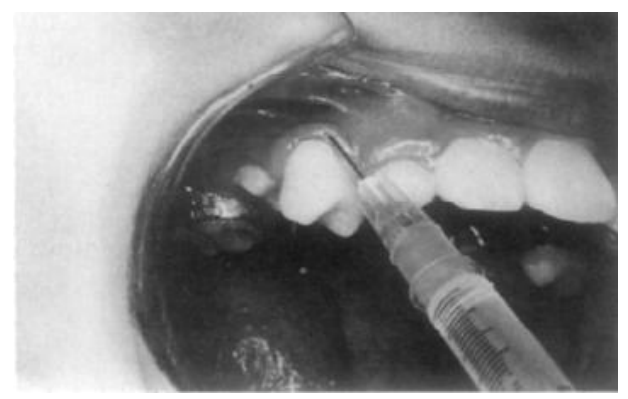

Gambar 5. Injeksi $\mathrm{PGE}_{1}$ pada submukosa gigi 15. (Sumber: Yamasaki K, Shibata Y, Imai S, Tani Y, Shibasaki Y, Fukuhara T. Clinical application of PGE1 upon orthodontic tooth movement. Am J Orthod 1984; 85: 508-18). ${ }^{24}$

\section{PEMBAHASAN}

Gaya ortodonti yang diaplikasikan pada gigi akan menyebabkan terjadinya perubahan pada ligamen periodontal, deformasi tulang, dan trauma jaringan. Selanjutnya akan terjadi transduksi sinyal, yaitu perubahan dari gaya mekanik ke dalam bentuk kejadian molekular., ${ }^{3,26}$
Prostaglandin terlibat dalam transduksi sinyal. Harrel dkk melakukan penelitian dengan mensementasi screw ortodonti pada dasar cawan petri yang berisi kultur sel yang mirip osteoblast, sehingga terjadi distorsi mekanis pada membran sel. Peristiwa yang terjadi adalah: (1) aktivasi fosfolipase $A_{2}$ yang diikuti oleh pelepasan asam arakidonat, sehingga menyebabkan sintesis $\mathrm{PGE}_{2}$ yang cepat (tiga kali lipat) dalam waktu 5 menit, (2) hal ini akan mengaktivasi adenylate cyclase dan peningkatan sementara cAMP intraselular, serta (3) peningkatan konsentrasi ion kalsium intraselular dan stimulasi sintesis DNA. ${ }^{5}$

Prostaglandin disintesis melalui berbagai stimulus, termasuk oleh proses inflamasi. Dalam bidang ortodontisia, gaya yang diaplikasikan untuk menggerakkan gigi akan menyebabkan terjadinya inflamasi lokal, yang kemudian akan meningkatkan permeabilitas vaskular dan menstimulasi infiltrasi seluler. Limfosit, monosit, dan makrofag akan berinfiltrasi ke dalam jaringan inflamasi tempat prostaglandin dilepaskan. Prostaglandin kemudian akan mengaktifkan adenylate cyclase, suatu enzim yang mengkatalisis perubahan ATP menjadi cAMP, sehingga akan menyebabkan peningkatan jumlah cAMP intraselular. Selain itu, jumlah kalsium intraseluler juga akan meningkat. cAMP dan kalsium merupakan messenger kedua intraseluler yang penting sebagai modulator dari osteoklas dan resorpsi tulang. Prostaglandin akan menyebabkan terjadinya resorpsi tulang, bukan hanya melalui peningkatan jumlah dan ukuran osteoklas, tetapi juga dengan menstimulasi aktivasi osteoklas yang telah ada. ${ }^{20-21,24,29}$

Proses pembentukan prostaglandin dari asam arakidonat memerlukan enzim siklooksigenase. Enzim siklooksigenase dapat dihambat oleh obat antiinflamasi non-steroid, seperti aspirin (asam 
asetilsalisilat). Aspirin akan mentransfer satu gugus asetil ke enzim tersebut, sehingga akan membuat enzim menjadi tidak aktif secara ireversibel. NSAID yang lain, seperti ibuprofen bekerja sebagai inhibitor reversibel dari siklooksigenase. ${ }^{18}$ Pemberian NSAID akan mempengaruhi aktivitas osteoklas sehingga menurunkan kecepatan pergerakan gigi. Kehoe dkk menemukan bahwa pemberian ibuprofen secara signifikan menghambat produksi PGE pada ligamen periodontal, sehingga menurunkan kecepatan pergerakan gigi ortodontik. Sebaliknya, pemberian asetaminofen tidak mempengaruhi kecepatan pergerakan gigi ortodontik. ${ }^{30}$

Asetaminofen, atau yang lebih dikenal dengan parasetamol, merupakan analgesik yang sering digunakan. Efek anti inflamasi dari asetaminofen hampir tidak ada. Tidak seperti NSAID lainnya yang bekerja dengan cara menghambat COX-1 dan/atau COX-2, baru-baru ini ditemukan bahwa parasetamol ternyata bekerja dengan cara menghambat COX-3, suatu isoform siklooksigenase yang belum diketahui sebelumnya, yang hanya terdapat pada otak dan korda spinalis. Oleh karena itu, parasetamol memiliki efek minimal terhadap sintesis prostaglandin. Asetaminofen dapat digunakan sebagai pilihan analgesik untuk mengatasi rasa sakit pada perawatan ortodontik tanpa mengganggu pergerakan gigi. ${ }^{16,30-31}$

Pada penelitian Yamasaki, digunakan lidokain $2 \%$ yang mengandung epinefrin. Lidokain dapat mengurangi reaksi sakit yang ditimbulkan oleh PGE. Epinefrin yang terkandung dalam lidokain dapat menyebabkan vasokonstriksi pembuluh darah lokal, sehingga menyebabkan retensi yang lama dari PGE dan meningkatkan efektivitasnya. ${ }^{24}$

Menurut Lee, injeksi berulang kali pada regio lokal dapat menimbulkan rasa takut pasien dan menyebabkan masalah dalam perawatan medis. Selain itu, vasokonstriksi yang ditimbulkan oleh larutan lidokain pada pemberian PGE secara lokal, seperti yang dilakukan pada penelitian Yamasaki, akan menekan reaksi inflamasi yang dibutuhkan untuk terjadinya resorpsi tulang. Dia melaporkan dari hasil penelitiannya bahwa pemberian sistemik $\mathrm{PGE}_{1}$ melalui intravena lebih efektif dan menghasilkan lebih banyak resorpsi tulang daripada injeksi lokal. Akan tetapi, Lee mengakui bahwa cepatnya inaktivasi $\mathrm{PGE}_{1}$ pada paru-paru, serta adanya beberapa efek samping seperti iritasi lokal dan flebitis terjadi pada metode ini. Konsentrasi maksimal untuk pemberian $\mathrm{PGE}_{1}$ secara sistemik dan lokal tanpa menyebabkan aksi umpan balik ataupun efek samping adalah 90 $\mathrm{g} / \mathrm{ml}$ untuk pemberian sistemik dan $20 \mathrm{~g} / \mathrm{ml}$ untuk pemberian lokal. ${ }^{29}$

Leiker dkk meneliti efek jangka panjang dari berbagai konsentrasi dan frekuensi injeksi $\mathrm{PGE}_{2}$ eksogen terhadap kecepatan pergerakan gigi pada tikus. Hasil penelitian menunjukkan bahwa tidak ada perbedaan signifikan pergerakan gigi antara injeksi tunggal dan injeksi berulang, ataupun antara kelompok dengan berbagai konsentrasi. $\mathrm{PGE}_{2}$ pada konsentrasi rendah, yaitu 0,1-1,0 g, cukup efektif untuk meningkatkan pergerakan gigi ortodontik. Akan tetapi, terdapat juga peningkatan resiko terjadinya resorpsi akar seiring dengan meningkatnya konsentrasi dan frekuensi injeksi $\mathrm{PGE}_{2}$, walaupun tidak signifikan. ${ }^{32}$

Banyaknya kekurangan dari pemberian prostaglandin, menuntun para peneliti untuk menguji pemakaian misoprostol, suatu analog $\mathrm{PGE}_{1}$ sintetik, dalam mempercepat pergerakan gigi. Pemberian misoprostol (100 g/kg) dua kali sehari pada marmut dalam penelitian Kehoe dkk, menunjukkan peningkatan kecepatan pergerakan gigi ortodontik. ${ }^{30}$ Sedangkan Sekhavat dkk melaporkan bahwa misoprostol efektif dalam 
meningkatkan pergerakan gigi pada dosis $10-25$ $\mathrm{g} / \mathrm{kg}$, dua kali sehari, dan misoprostol tidak signifikan menambah resiko resorpsi akar. Mereka menyatakan bahwa pemberian misoprostol secara oral dapat digunakan untuk meningkatkan kecepatan pergerakan gigi dalam perawatan ortodontik dengan resiko resorpsi akar yang minimal. ${ }^{33}$ Usaha lain yang dilakukan untuk mengurangi jumlah resorpsi akar adalah memberikan injeksi kalsium glukonat bersamaan dengan injeksi $\mathrm{PGE}_{2}$, seperti yang dilakukan oleh Seifi dkk dalam penelitiannya. Ion kalsium yang berasal dari kalsium glukonat dapat mencegah resorpsi akar pada tikus. ${ }^{8}$

\section{SIMPULAN}

Pergerakan gigi ortodontik merupakan suatu proses yang kompleks yang melibatkan banyak faktor. Gaya ortodontik yang diberikan akan menyebabkan trauma jaringan, kompresi ligamen periodontal, dan deformasi tulang. Selanjutnya akan terjadi transduksi sinyal, yaitu perubahan dari gaya mekanik ke dalam bentuk kejadian molekuler. Prostaglandin terlibat dalam transduksi sinyal tersebut. Deformasi mekanis yang terjadi pada sel-sel ligamen periodontal akan menyebabkan pelepasan messenger pertama, termasuk prostaglandin. Messenger pertama ini kemudian akan menstimulasi pelepasan messenger kedua, termasuk cAMP dan kalsium intraseluler, yang selanjutnya akan mengaktifkan osteoklas. Selain itu, prostaglandin yang berikatan pada reseptor EP4 di permukaan sel osteoblas akan memicu pembentukan RANKL, yang jika berikatan dengan RANK, yang terdapat pada permukaan sel progenitor osteoklas, akan mengaktifkan osteoklas untuk meresorpsi tulang.

Sejumlah peneliti telah membuktikan pemberian prostaglandin dapat mempercepat hampir dua kali lipat pergerakan gigi ortodontik.
Diharapkan dapat ditemukan suatu preparat yang analog dengan prostaglandin tanpa efek rasa sakit dan kemungkinan resorpsi akar, sehingga dapat digunakan dengan aman dan efisien untuk mempercepat pergerakan gigi. Hal ini dapat menjadi terobosan dalam perawatan ortodontik sehari-hari dan tentu saja akan memberi keuntungan baik bagi pasien maupun para ahli ortodontik.

\section{DAFTAR PUSTAKA}

1. Proffit WR. Contemporary orthodontics. $4^{\text {th }}$ ed. St. Louis: Mosby Elsevier; 2007.p.331-43.

2. Singh G. Texbook of orthodontics. New Delhi: Jaypee Brothers Medical Publisher; 2004. p.198-204.

3. Bhalajhi SI. Orthodontics:The art and science. $3^{\text {rd }}$ ed. New Delhi: Arya (MEDI) Publishing House; 2006. p.181-94.

4. Foster TD. Buku ajar ortodonsi. Edisi 3. Alih bahasa:Yuwono L.Jakarta:EGC;1997.p.168-85.

5. Meikle MC. The tissue, cellular, and molecular regulation of orthodontic tooth movement: 100 years after Carl Sandstedt. Eur J Orthod 2006; 28: 221-40.

6. Mulyani. Biomekanik pergerakan gigi. Jakarta: Widya Medika; 1994. p.29-48.

7. Masella RS, Meister M. Current concepts in the biology of orthodontic tooth movement. Am J Orthod Dentofac Orthop 2006; 129: 458-68.

8. Valiathan A, Dhar S. Prostaglandin and enhanced orthodontic tooth movement: in search of the silver bullet. Current Sci 2006; 90: 311-3.

9. Yamasaki K, Shibata Y, Fukuhara T. The effect of prostaglandin on experimental tooth movement in monkeys (Macaca fuscata). J Dent Res 1982; 12: 1444-6.

10. Cardaropoli D, Gaveglio L. The influence of orthodontic movement on periodontal tissues level. Semin Orthod 2007; 13: 234-45.

11. Yamasaki K, Shibasaki Y, Fukuhara T. Behavior of mast cells in periodontal ligament associated with experimental tooth movement in rats. J Dent Res 1982; 61: 1447-50. 
12. Nanda R. Biomechanics and esthetic strategies in clinical orthodontics. St. Louis: Elsevier Saunders; 2005. p.17-27.

13. Smith JB. Prostaglandin and related eicosanoids. In: DiPalma JR, DiGregorio GJ (Ed). Basic pharmacology in medicine. $3^{\text {rd }}$ ed. New York: McGraw-Hill Publishing Company; 1990. p.181-7.

14. Ganong WF. Buku ajar fisiologi kedokteran. Ed 17. Alih bahasa: Widjajakusumah MD. Jakarta: EGC; 1998. p.303-5, 376-88.

15. Bartzela T, Türp JC, Motschall E, Maltha JC. Medication effects on the rate of orthodontic tooth movement: a systematic literature review. Am J Orthod Dentofac Orthop 2009; 135: $16-26$

16. Sandy JR, Farndale RW, Meikle MC. Recent advances in understanding mechanically induced bone remodeling and their relevance to orthodontic theory and practice. Am J Orthod Dentofac Orthop 1993; 103: 212-22.

17. Lieberman M, Marks A. Mark's basic medical biochemistry: a clinical approach. $3^{\text {rd }}$ ed. Philadelphia: Lippincott Williams and Wilkins; 2009. p.671-84.

18. Foegh ML, Ramwell PW. The eicosanoids: Prostaglandins, thromboxanes, leukotrines, and related compounds. In: Katzung BG (Ed). Basic and clinical pharmacology. $9^{\text {th }}$ ed. New York: The McGraw-Hill Companies; 2004. p.298-312.

19. Pilbeam CC, Harrison JR, Raisz LG. Prostaglandin and bone metabolism. In: Bilezikian JP, Raisz LG, Rodan GA (Ed). Principles of bone biology. San Diego: American Press,Inc.; 1996. p.715-22.

20. Ilyina A, Alvarado GD, Trimmer RE, Garcia LMG, Villarreal SJA, Martinez HJL, dkk. Comparative study of the effects of administration of $\mathrm{PGE}_{1}, \mathrm{PGE}_{2}$, and enzymatic preparation with prostaglandin $\mathrm{h}$-synthase activity on orthodontic tooth movement. Biocatalysis 2000; 41: 81-4.

21. Raisz LG. Physiologic and pathologic roles of prostaglandins and other eicosanoids in bone metabolism. J Nutr 1995; 125: 2024S-7S.

22. Fracon RN. Teofilo JM. Satin RB, Lamano T. Prostaglandins and bone: Potential risks and benefits related to the use of nonsteroidal antiinflammatory drugs in clinical dentistry. J Oral Sci 2008; 50: 247-52.

23. Yamasaki K, Shibata Y, Imai S, Tani Y, Shibasaki Y, Fukuhara T. Clinical application of prostaglandin $\mathrm{E}_{1}$ upon orthodontic tooth movement. Am J Orthod 1984; 85: 508-18.

24. Machwate M, Harada S, Leu CT, et al. Prostaglandin receptor EP4 mediates the bone anabolic effects of $\mathrm{PGE}_{2}$. Mol Pharmacol 2001; 60: 36-41.

25. Yamasaki K, Miura F, Suda T. Prostaglandin as a mediator of bone resorption indiced by experimental tooth movement in rats. J Dent Res 1980; 59: 1635-42.

26. Niaki EA, Yazdi E, Zamani A. The effects of $\mathrm{PGE}_{1}$ and indomethacin on orthodontic tooth movement in rat. Acta Medica Iranica 1999; 37: 215-9.

27. Chumbley AB, Tuncay OC. The effect of indomethacin (an aspirin-like drug) on the rate of orthodontic tooth movement. Am J Orthod 1986; 89: 312-14.

28. Lee W. Experimental study of the effect of prostaglandin administration on tooth movement-with particular emphasis on the relationship to the method of $\mathrm{PGE}_{1}$ administration. Am J Orthod Dentofac Orthop 1990; 98: 231-41.

29. Kehoe MJ, Cohen SM, Zarrinnia K, Cowan A. The effect of acetaminophen, ibuprofen, and misoprostol on prostaglandin $E_{2}$ synthesis and the degree and rate of orthodontic tooth movement. Angle Orthod 1996; 66: 339-50.

30. Polat O. Pain and discomfort after orthodontic appointments.Semin Orthod 2007;13:292-300.

31. Leiker BJ, Nanda RS, Currier GF, Howes RI, Sinha PK. The effects of exogenous prostaglandins on orthodontic tooth movements in rats. Am J Orthod Dentofacial Orthop 1995; 108: 380-8.

32. Sekhavat AR, Mousavizadeh K, Pakshir HR, Aslani FS. Effect of misoprostol, a prostaglandin $E_{1}$ analog, on orthodontic tooth movement in rats. Am J Orthod Dentofac Orthop 2002; 122: 542-7. 